\title{
Information disclosure, CEO overconfidence, and share buyback completion rates
}

\author{
Dimitris Andriosopoulos ${ }^{1, \hbar}$ Kostas Andriosopoulos $^{2}$ and Hafiz Hoque ${ }^{1}$
}

March 2013

\begin{abstract}
An open market share buyback is not a firm commitment, and there is limited evidence on whether firms repurchase the intended shares. Unlike US studies, we use data from unique UK regulatory and disclosure environment that allows to accurately measure the share buyback completion rates. We show that information disclosure and CEO overconfidence are significant determinants of the share buyback completion rate. In addition, we find that large and widely held firms that conduct subsequent buyback programs and have a past buyback completion reputation exhibit higher completion rates. Finally, we assess whether other CEO characteristics affect buyback completion rates and find that firms with senior CEOs who hold external directorships and have a longer tenure as CEO are more likely to complete the buyback programs. In sum, our results suggest there is a clear relationship between information disclosure, CEO overconfidence, and buyback completion rates.
\end{abstract}

JEL classification: G14; G30; G32; G35; M40.

Keywords: Buyback reputation; CEO characteristics; CEO overconfidence; Information disclosure; Share buyback completion rate

${ }^{\ddagger}$ Corresponding author: (D. Andriosopoulos), Tel.: +44 (0) 179229 5180, E-mail: D.Andriosopoulos@swansea.ac.uk

${ }^{1}$ Swansea University, Singleton Park, SA2 8PP, Swansea, Wales, United Kingdom

${ }^{2}$ ESCP Europe Business School, 527 Finchley Road, NW3 7BG, London, United Kingdom

We thank Yilmaz Guney, Meziane Lasfer, Aneel Keswani, Stephen Young, Isaac Tabner, Dylan Thomas, Reza Arabsheibani, Assad Jalili, the participants of the FEBS 2012 Conference in London, United Kingdom, and the 2010 EURO working group on efficiency and productivity analysis in Crete, Greece, for their helpful comments. In addition, we thank ESCP Europe for financial support. Finally, we thank Shuai Yang, Chen Tong, and Naman Mehta for their assistance in collecting the data. All remaining errors are our own. 


\section{Introduction}

When firms announce they intend to repurchase shares, the market reacts positively (Vermaelen, 1981; Ikenberry et al., 1995; Chan et al., 2004), even though such announcements are not firm commitments and, therefore, costless. Moreover, firms can consciously use share repurchase announcements to boost their share price while misleading shareholders, since there is no long-term economic benefit (Chan et al., 2010). However, share buyback announcements attract the market's scrutiny, preventing bad firms from mimicking good firms. Thus, buyback announcements can be credible, which justifies the positive market reaction (Bhattacharya and Dittmar, 2003).

Typically, firms are not required to disclose their intention to conduct an open market share buyback, though many firms do. Interestingly, when firms announce they intend to repurchase shares, some choose to disclose explicit information on the intended buyback while others do not. When firms make no share buyback announcements, managers reserve the flexibility to repurchase shares before any mispricing discovery by the market. When firms announce only their intention to repurchase shares without explicit details, managers send a mispricing signal to the market that reduces the managers' flexibility in taking advantage of any early mispricing. When firms disclose the full details of their intended buyback program, the firms signal to the market that they have a clear strategy and intention to repurchase shares (Ikenberry and Vermaelen, 1996). Therefore, understanding why firms announce explicit information and whether information disclosure is related to buyback completion rates is important. We contribute to the literature by testing whether disclosing explicit information (or not) about the intended buyback program can serve as a strong indicator of firms' real intentions to deliver on the promise to repurchase shares. We find strong evidence supporting our expectations that announcing explicit information about the shares intended to be repurchased can serve as a 
strong signal of firms" "commitment" to follow through with their announced buyback programs.

When firms intend to repurchase shares, managers, and effectively chief executive officers (CEOs), reserve flexibility on the timing of and method for implementing the buyback program (Guay and Harford, 2000; Jagannathan et al., 2000). Malmendier and Tate (2005) find that managerial overconfidence influences corporate investment decisions. In addition, Malmendier and Tate (2008) show that overconfident CEOs make more acquisitions and the market reacts negatively to such acquisitions. Malmendier et al. (2011) show that overconfident managers view their firms as undervalued and external financing as expensive, and thus issue less equity compared to their peers. In addition, they show that overconfidence and early life experience explain firms' capital structure variations. Hirshleifer et al. (2012) find that firms with overconfident CEOs have higher return volatility, invest more in innovations, obtain more patents and patent citations, and achieve greater success in innovative research and developments. In this paper, we examine whether overconfident CEOs perceive their equities as undervalued and complete the announced buyback programs. To our knowledge, this is the first study to investigate the impact of CEO overconfidence and other CEO traits on share buyback programs and their implementation. We find that overconfident CEOs perceive their shares as undervalued and have a higher buyback completion rate.

Another stream in the literature shows that CEO traits can have a significant impact on corporate decisions, such as the decisions affecting capital structure (Cronqvist et al., 2012), financing choices (Malmendier et al., 2011), and risk-taking attitude (Masulis and Mobbs, 2011). Frank and Goyal (2007) find that CEO characteristics can have a significant impact on the variation in leverage across firms. Yim (2013) shows that CEO age is positively related to mergers and acquisitions. Song and Thakor (2006) deal with the 
incentives for a $\mathrm{CEO}$ to provide less precise signals about projects proposed to the board, and Hermalin and Katz (2000) develop a model in which CEOs have an incentive to choose a less informative regime that would be desired by the owners.

CEOs with a long tenure in a firm are more likely to be entrenched, thus exerting more influence with low levels of ownership simply by virtue of tenure (Morck et al., 1988) and avoiding any agency monitoring (Hill and Phan, 1991). Moreover, powerful and entrenched CEOs can influence the board composition toward their preference, leading to a weakening of board monitoring (Hermalin and Weisbach, 1998). Consequently, tenured CEOs are less likely to succumb to shareholders' pressure to make a payout in the form of share buybacks to reduce potential agency costs. Overall, we have limited knowledge on the potential impact that varying CEO characteristics have on corporate financing decisions and in effect on payout policies. We relate CEO traits and disclosure policies with share buyback completion rates and find that firms with more senior CEOs who have more corporate connections and longer tenure as a CEO are significantly more likely to complete the firms' share buyback programs.

Though the information disclosure precedes buyback announcements, its relation with buyback completion rates may be affected by the omitted factors driving disclosures and buyback completion rates. It is important that we separate out the real effects of information disclosures from the effects of company characteristics and CEO characteristics that provide disclosure. Thus, we consider information disclosure as endogenous with the buyback completion rate. We conduct a Hausman (1978) test of endogeneity and model information disclosure and buyback completion rate in a two-stage regression framework as in Brockman et al. (2008). Although we find that information disclosure is endogenous, a positive relationship between information disclosure and the buyback completion rate survives after controlling for endogeneity. 
Until the mid-2000s, the only disclosure requirement regarding open market buyback programs in the United States (US) was the quarterly reporting of the number of shares outstanding. Therefore, tracing stock repurchases connected to a specific buyback announcement was challenging and became questionable whether firms are committed to completing the intended buyback programs. Stephens and Weisbach (1998) find that the buyback completion rates can significantly deviate from the intended target initially set by the firms. ${ }^{1}$ Bonaimé (2012) uses several buyback proxies and finds that the average completion rate in a sample of US listed firms is approximately $73 \%$. According to Kim et al. (2004), US disclosure requirements "are among the least stringent" of all the major stock exchanges the researchers examined. Following a change in US regulations in 2004, firms are held to a higher degree of disclosure regarding share buyback program, but even so, these requirements do not allow for accurate and timely measurement of buyback completion rates. ${ }^{2}$ Banyi et al. (2008) assess the accuracy of the share buyback proxies commonly used in the US literature and find strong evidence suggesting these proxies suffer from inaccuracies, potentially leading to a significant distortion of the evidence and interpretations reported in the existing literature. This has been only partially addressed following the change in US regulations in 2004; firms are now required to disclose buyback trades but on quarterly statements.

\footnotetext{
${ }^{1}$ Fama and French (2001) adjust the changes in Treasury stock used by Stephens and Weisbach (1998) to account for the cancellation of Treasury shares; however, the researchers' focus is not measuring the buyback programs' completion rates.

${ }^{2}$ In particular, according to the change in Rule 10b-18 of the SEC Act of 1934 in the US, concerning the disclosure requirements of open market buybacks, listed firms are required to report on a monthly basis the exact volume and price data of their repurchasing activity in their prerequisite quarterly filings. This change in Rule 10b-18 was introduced on December 17, 2003; however, it became effective for all quarterly and annual filings for periods ending on or after March 15, 2004.
} 
We overcome the unavoidable measurement and reporting timing inaccuracies of the US studies by using accurate daily share buyback data from the more rigorous disclosure environment of the $\mathrm{UK} .{ }^{3} \mathrm{UK}$ regulations mandate that firms disclose the repurchased shares and the price paid on the day when the actual repurchase trades occur, until the start of the following trading day. Since the UK has similar institutional and regulatory frameworks to the US but a more stringent disclosure regime, even compared to other European countries where share repurchase trades are reported monthly, it constitutes a unique setting for analyzing the drivers of share buyback completion rates.

In sum, we find that greater information disclosure and CEO overconfidence have a significant influence on firms completing their intended buyback programs. We also find that CEO age, connectedness, and tenure affect share buyback completion, while controlling for firm-specific characteristics. Moreover, we find that firms that initiate their buyback program shortly after the announcement and conduct repeat buyback programs are more likely to have higher buyback completion rates.

The rest of the paper is organized as follows. In section 2, the literature is reviewed and the hypotheses set. In section 3, the data, variable definitions, estimation methods, and descriptive statistics are discussed. In section 4, the results for the factors that influence share buyback completion rates are discussed. The robustness tests are presented in section 5. The conclusions are in section 6.

\footnotetext{
${ }^{3}$ Oswald and Young (2004) in the UK, Ginglinger and Hamon (2007) in France, and Zhang (2005) in Hong Kong use daily data on share repurchases and the respective actual repurchase trades; however, the researchers do not focus on the completion rates of the announced share repurchase programs or on identifying the factors that affect the programs' completion.
} 


\section{Review of literature and hypotheses}

\subsection{Disclosing details on buybacks and buyback completion rate}

Corporate disclosures could alleviate the adverse selection problems (Verrecchia, 2001) and increase the liquidity of shares or reduce the agency cost (Hermalin and Weisbach, 2012) by mitigating the information asymmetries. Previous studies show that an increase in voluntary disclosure reduces firms' cost of capital. Several papers study the relationship between disclosure ratings from the Association for Investment Research (AIMR) and the cost of capital measures such as bid-ask spread and trading volume (e.g., Healey et al., 1999). Some studies use self-constructed measures of disclosures and link these measures with measures of the cost of capital (e.g., Botosan, 1997). Leuz and Verrecchia (2000) examine the link between the choice of accounting regime and the cost of capital and find that when firms increase voluntary disclosures their cost of capital decreases. Leone et al. (2007) examine the dollar detailed use of IPO proceeds (as disclosed by the issuer) and its relationship with underpricing. They show that IPO underpricing is lower when companies disclose more specific information. ${ }^{4}$

Hermalin and Weisbach (2012) develop a formal model of information disclosure and corporate governance. They show that larger firms adopt stricter disclosure rules than smaller firms. Their model suggests that greater or more informative disclosure could lead in changes in real investments, favoring short-term investments as opposed to long-term investments. Their model also suggests that in greater or more informative disclosure industries management pay and turnover are higher than in industries with less informative disclosure.

After the share buyback is authorized, managers can follow three main routes for repurchasing shares in the open market. First, the managers can make no announcement of

\footnotetext{
${ }^{4}$ For a detailed review of the recent literature on corporate voluntary disclosures, see Beyer et al. (2010).
} 
their intention to repurchase shares. Thus, the managers reserve the option of an "earlyadoption" strategy and use their inside information to repurchase shares before the undervaluation is discovered by the market (Ikenberry and Vermaelen, 1996). Second, managers can announce their intention to repurchase shares but without disclosing specific details of the intended program. This way, managers reserve the option to repurchase shares when shares are mispriced but lose the advantage of exploiting a significant mispricing, since the managers already alerted the market to a potential undervaluation. Therefore, this "wait-to-adopt" strategy has a smaller advantage against the market in exploiting significant undervaluations and is inferior to the "early-adoption" strategy (Ikenberry and Vermaelen, 1996). Third, when the full details of the intended buyback program are disclosed, the announcement bears some cost, since the inherent flexibility of repurchasing undervalued shares is reduced, and by doing so, managers are trying to reposition the market's valuation within their perceived "fair" value levels. However, enhancing the information disclosure increases the credibility of the managers' intention to repurchase shares when future share prices are below their "fair" price levels. Even though part of the flexibility to repurchase shares before the market realizes the firm's undervaluation is lost, managers can still exploit future mispricing opportunities arising from share price deviations from their fair value. This allows managers to accrue the superior informational advantage back to the firm, and in the absence of potential profitable investments, managers prefer to repurchase shares to maximize the wealth of long-term investors (Ikenberry and Vermaelen, 1996) and reduce agency costs.

We argue that firms disclosing specific information about their buyback program have a stronger commitment and a clear strategy for implementing and completing the announced buyback program. We test for this level of commitment with the dummy variable Buyback Information, which takes the value of one when an announcement of the 
firm's intention to buy back shares contains explicit information about the intended buyback program and zero when no information is disclosed. ${ }^{5}$ Hence, this hypothesis is formally stated as follows:

H1. Companies that disclose information on buyback programs have higher completion rates.

\subsection{CEO characteristics}

\subsubsection{CEO overconfidence}

Managerial overconfidence and miscalibration can have significant explanatory power for a number of corporate decisions. ${ }^{6}$ For instance, Malmendier et al. (2011) show that overconfident managers who believe that their firm is undervalued view external (equity) financing as overpriced. Therefore, managers use less external finance (equity) compared to their peers. Ben-David et al. (2012) show that managerial miscalibration is an important determinant of several corporate finance activities. The authors report that miscalibrated managers invest more, use more debt, are less likely to pay dividends, are more likely to repurchase shares, and use more long-term debt compared to short-term debt. Hirshleifer et al. (2012) assert that overconfident CEOs tend to overestimate the net discounted expected payoffs from uncertain ventures, either because of a general tendency to expect good outcomes or because the CEOs overestimate their chances of success. The authors find that firms with overconfident CEOs have higher return volatility, invest more in innovations, obtain more patents and patent citations, and achieve higher success in innovative research and developments. Malmendier and Tate (2008) find that

\footnotetext{
${ }^{5}$ We consider as buyback announcements with explicit information those announcements stating the number of shares to be repurchased, or the amount in GB pounds to be used for open market buybacks, or a percentage of the firm's capital to be repurchased.

${ }^{6}$ We thank an anonymous referee for suggesting a potential link between CEO overconfidence and buyback completion rates.
} 
overconfident CEOs make more acquisitions and the market reactions for such CEOs are more negative. Ferris et al. (2013, forthcoming) extend CEO overconfidence in the context of international M\&As. Malmendier and Tate (2005) propose that overconfident managers are optimistic about investment opportunities. However, these managers overestimate the value of their firms' equity. Therefore, managerial overconfidence is related to managers perceiving their stock as undervalued.

CEOs who do not exercise their in-the-money stock options are considered overconfident (Malmendier et al., 2011) and believe that their firm's share price is undervalued. Consequently, they are more likely to buy back shares to exploit this perceived undervaluation. Hence, we hypothesize that managerial overconfidence is a determinant of the buyback completion rate. Similar to Malmendier et al. (2011), we measure CEO overconfidence as a late option exercise by CEOs, which is a dummy variable that takes the value of one for those CEOs who at any point during the sample period hold an option until the year of expiration even though the option is at least $40 \%$ in the money entering its final year. We formally state the testable hypothesis as follows: H2. CEO overconfidence is positively related to buyback completion rates.

\subsubsection{Other CEO characteristics}

The existing literature reports that CEO and managerial personnel characteristics have a significant impact on corporate policies. For example, Cronqvist et al. (2012) show that CEOs' personal behavior and personal leverage decisions can have a significant impact on the capital structure decisions of the firms the CEOs manage. Malmendier et al. (2011) show that managerial traits can explain the firms' financing choices. Masulis and Mobbs (2011) show that firms with inside directors who hold outside directorships have better operating performance and market-to-book ratios, especially when monitoring is 
more difficult. The evidence reported in the literature on the impact of CEO traits on value creation is mixed.

Many studies show that network ties appear to enhance value by creating a free flow of information (Hochberg et al., 2007, for venture capital investment; Fracassi, 2008, for corporate investment). However, Guner et al. (2008) show that network ties tend to destroy value. In addition, Hwang and Kim (2009) argue that network connections through external directorships lead to higher executive compensation. Moreover, the authors argue that when boards are conventionally and socially independent CEO compensation decreases. This suggests that CEOs who are connected can strengthen their control over the board, leading to stronger CEO entrenchment. Fracassi and Tate (2012) show that powerful CEOs strengthen their position in the firm by hiring directors with whom the CEOs have social ties, leading to weakened monitoring. In extension, we argue that if a CEO is more connected, via external directorships, then weak motivation will persist to complete the buyback program. However, if more connected CEOs are overconfident, we expect a positive relationship between the buyback completion rate and CEO connectivity. We control for CEO connectivity with the variable Number of Directorships Held, which is the number of companies in which the CEO is serving as director at the time.

Tenure can potentially provide CEOs with more time to align their interests with those of the board's. Moreover, tenured CEOs can strengthen their influence over the board, leading to an increase in the CEO's power. Hill and Phan (1991) find that tenure provides CEOs with time to avoid monitoring and any incentive alignment mechanisms. For instance, Morck et al. (1988) argue that managers can be deep-rooted with relatively low levels of ownership simply by virtue of the managers' tenure with the firm, status as founder, or personality. Hermalin and Weisbach (1998) develop a model of the balance of power between the CEO and other directors that predicts that board independence declines 
over the course of a CEO's tenure. We argue that CEOs with longer tenure become more entrenched, and therefore have greater influence over the board and effectively the shareholders. Consequently, tenured CEOs are less likely to succumb to shareholder pressure to make a payout, in the form of share buyback programs, to reduce potential agency costs. Thus, we expect to find a negative relationship between CEO tenure and share buyback completion rates. In contrast, if CEO confidence increases with tenure (as in Yim, 2013), we would expect a positive relationship. We include the variable $C E O$ Tenure, which is the difference between the start date as CEO and the date of the buyback announcement, expressed in years.

CEO age can have a significant impact on decision making, since younger persons may be more prone to risk taking. However, experience grows with age, allowing executives to take more risks, but sensibly. Evidence suggests that risk aversion and age are nonlinear, as personal risk aversion tends to increase with age until the age of 70 and then decline (Shefrin, 2005). Moreover, Agarwal et al. (2007) report evidence suggesting that the sophistication of financial decisions varies with age. Yim (2013) show that CEO age is positively related to acquisition behavior. Therefore, we include in our analysis the variable Age to test whether executives who are more senior are more likely to stick to their commitments and complete the buyback program. CEO Age is the difference between the CEO's date of birth and the year of the buyback announcement expressed in years. In addition, we proxy for CEO experience with the Number of Companies Worked For, which is the number of companies at which the CEO has worked as a director until the time of the buyback announcement. We argue that CEOs want to maintain their reputation, the fact that the firm, and effectively the CEO, is credible and delivers on its promise of making a payout in the form of buyback programs. 
Furthermore, we examine whether CEO education has an impact on share buybacks. Chevalier and Ellison (1999) find that fund managers with master of business administration degrees (MBAs) tend to take on more systematic risk. Therefore, we assess the impact of the CEO's education with the variable Business Education, which is a dummy equal to one if the CEO received an education in business-related studies and zero otherwise. In addition, we include the variable Highest Education, which is a dummy equal to one if a CEO has a master's degree or above. We further examine whether pursuing a business-oriented career has an impact on buyback completion. Business or Non-business Career is a dummy variable equal to one if the CEO pursued a businessoriented career.

Barber and Odean (2001) suggest that men tend to be more overconfident compared to women. Therefore, we control for CEO Gender, which is a dummy variable with the value of one if the CEO is male and zero otherwise. Moreover, we include the dummy variable Founder, which takes the value of one if the CEO is the firm's founder and zero otherwise. We also include the dummy variable Internally, which takes the value of one if the CEO was appointed internally and zero otherwise. Finally, since we investigate UK corporations, we control for the CEO's Nationality, which is a dummy variable with a value of one if the CEO is a British national and zero otherwise.

Hackbarth (2008) developed a model in which managers with growth perceptions bias repurchase shares when the managers perceive their equity as undervalued. BenDavid et al. (2012) use demographic profiles of managers to examine whether certain characteristics are associated with overconfidence. In particular, the researchers use age, professional experience, education, and gender to test whether they are related to overconfidence. They relate overconfidence to several corporate decisions such as investment and financing decisions. Regarding share repurchases, the researchers propose 
that overconfident managers engage in more share repurchases. Therefore, we propose the following hypothesis:

H3. CEO characteristics are related to CEO confidence and have a significant impact on buyback completion rates.

\section{Data and methodology}

\subsection{Share buyback data}

The sample is constructed by identifying all the announcements of firms' intentions to repurchase ordinary shares in the open market from hand-collected data, reported in news articles posted in the Perfect Analysis and Factiva databases from 1 January 1997 through 31 December 2006. These databases report all news announcements available in the press made by UK corporations about open market share repurchases. The sample is refined to involve solely firms that announce their intention to repurchase ordinary shares in the open market, thus excluding announcements concerning the repurchase of B shares or preference shares. Additionally, we control the sample for American Depositary Receipts (ADRs) and cross-country listings. Furthermore, the firms included in the sample are required to list their share prices on DataStream and their accounting data on Worldscope. Finally, we exclude financial institutions from our sample. Thus, the final sample contains 400 announcements of intention to repurchase shares in the open market from corporations primarily listed in the United Kingdom.

We collect our sample of open market share buyback trades from Zephyr, a database maintained by Bureau Van Dijk, for the corresponding publicly disclosed announcements of intention to repurchase shares. Following, we take random samples of buyback trades taken from Zephyr, and we cross-check their accuracy, i.e., date of execution and value of the trades against news strips taken from Factiva. Thus, we ensure the accuracy of measuring the number of the repurchased shares, and more importantly, in a timely 
manner, since they are reported on a daily basis. ${ }^{7}$ We identify 13,378 open market buyback trades.

For estimating the completion rate of the announced share repurchase programs, the total number of the reportedly repurchased shares is divided by the intended number of shares targeted at the time of the open market share repurchase announcement, which has been explicitly stated as the total number of shares. Alternatively, the rate is extrapolated by the firms' market value with the current price at the time of announcement (when the target percentage of shares to be repurchased is stated) or extrapolated from the relative value of the shares at the time of the announcement (when an explicit monetary value is disclosed in the announcement).

\subsection{CEO-specific characteristics}

We look for chief executive officers' details in Thomson One Banker, a database maintained by Thomson Reuters, which provides each director's name and position (past and current). In addition, this database provides the directors' start and resignation dates. We calculate Tenure as $C E O$ and Tenure in the firm from the start date to the departure date as CEO and as director, respectively. The database also provides the number of companies for which the director is a board member, and we collect that information as a proxy for CEO connectedness. A biography of the CEO is also provided in the database, from which we manually collect the CEO nationality and educational background. We complement any missing biographical information by searching past annual reports and other Internet sources and social networks such as LinkedIn. Finally, we collect all relevant data on CEO options from BoardEx and, in particular, options' vesting date,

\footnotetext{
${ }^{7}$ We randomly select $10 \%$ of our sample firms and collect the total number of repurchased shares from their fiscal year statements to validate the completion rates estimated from the collection of the daily actual share repurchase trades, and they show no significant qualitative and/or statistical differences.
} 
number of exercisable options, exercise price, and options exercised for our sample firms' CEOs.

\subsection{Firm-specific characteristics}

To estimate the firms' commitment to implementing and completing the announced buyback programs, we use the variable Completion Rate, which is the percentage of the actually repurchased shares relative to the number targeted at the time of the announcement. As in Rau and Vermaelen (2002) and Ikenberry et al. (2000), we control for a firm's information asymmetry and efficient pricing with the variable Size, defined as the natural logarithm of market capitalization.

Bonaimé (2012) finds that a firm's reputation for completing past buyback programs has a significant impact on the market reaction (Vermaelen, 1981; Ikenberry et al., 1995; Chan et al., 2007), which is not as high for firms with a poor history of completing past buyback programs. Thus, we control for a firm's past reputation for repurchasing shares by including the variable Buyback Reputation, which is the completion rate of the most recent buyback program implemented by firm $i$.

We argue that the fact that firms conduct more than one buyback program can serve as an indication of following through with their current buyback programs. Ikenberry et al. (2000) argue that managers could behave opportunistically and repurchase shares only when their respective prices are falling. Therefore, firms with consecutive buyback programs are more likely to behave opportunistically, since their primary goal is to distribute excess cash, leading to lower completion rates. Therefore, we include the dummy variable Buyback Repetition, which takes the value of one if a firm has announced its intention to buy back its shares in the past three years, and zero otherwise. In addition, we argue that if firms are not trading strategically and their primary goal for undertaking a share repurchase is to give their excess cash back to their shareholders, we expect to see 
firms beginning the open share repurchase program as early as possible, without any delays. Therefore, if a firm initiates its repurchase program as early as possible, this could be taken as the firm's commitment to its repurchase program. For that reason, we include Initiation Lag, which is the natural logarithm of the number of days starting from the day of the announcement until the day of the first buyback trade.

To control for the inherent flexibility that share repurchases offer managers on timing the repurchase trades (Jagannathan et al., 2000) when the stock is undervalued, we follow Bonaimé (2012) and Bargeron et al. (2011) and include the Standard Deviation of stock returns. This variable is estimated as the standard deviation of daily returns over the 200-trading-day period beginning 210 days before the announcement and ending 10 days before the announcement.

Moreover, we use additional control variables that are well established in the literature. To control for the impact of selling shares to satisfy existing stock option plans or additional stock grants (Ofek and Yermack, 2000; Babenko et al., 2012) on completing a share buyback program, we include the number of total options issued. We also control for the potential impact of firms repurchasing their shares due to conversion of debt into common stock, with the variable Convertible Debt, which is estimated as the value of convertible debt outstanding (in GB pounds) of firm $i$ at the year-end before the intention to buy back shares is announced. As a control of disclosure environment and firm-specific information asymmetry, we use the number of analysts following the firm (Number of Analysts) as in Jensen et al. (2004). We control for firm growth and perceived valuation with Market-to-Book (Ikenberry et al., 1995; Ikenberry et al., 2000), in addition to Excess Returns (measured as the cumulative excess return of firm $i$ relative to the FTSE All Share index for the 20 days $[-22,-2]$ relative to the announcement). We control for the impact of debt with Leverage, measured as the ratio of long-term debt over total assets (Jagannathan 
and Stephens, 2003). In addition, we control for the excess cash hypothesis (Dittmar, 2000; Brockman and Chung, 2001; Oswald and Young, 2008) with the proxy Cash, which is the ratio of net income before taxes plus depreciation and changes in deferred taxes and other deferred charges to total assets (Dittmar, 2000). ${ }^{8}$

We also control for the impact of agency costs (Easterbrook, 1984; Jensen, 1986) with the use of Ownership Concentration (Mitchell and Dharmawan, 2007; Andriosopoulos and Hoque, 2013) measured as the ratio of closely held shares ${ }^{9}$ over the total common shares outstanding before the repurchase announcement. We control for dividend substitution with open market share buyback programs and their tax efficiency (Grullon and Michaely, 2002) with the Dividend Yield (Mitchell and Dharmawan, 2007; McNally, 1999) before the buyback announcement. Alternatively, we use the variable Dividend Payout (Dittmar, 2000; Grullon et al., 2002) measured as the ratio of common cash dividends relative to the reported net income.

\subsection{Estimation methods}

To formally test our hypotheses, we form the following equation:

\footnotetext{
${ }^{8}$ Alternatively, we use as a proxy for cash the variables Expected Cash and Unexpected Cash as defined in Stephens and Weisbach (1998), and our results remain unaltered.

${ }^{9}$ The variable Closely Held Shares is taken from Worldscope and represents the following: shares held by insiders; shares held by officers, directors, and their immediate families; shares held in trust; shares of the company held by any other corporation (except shares held in a fiduciary capacity by banks or other financial institutions); shares held by pension/benefit plans; and shares held by individuals who hold 5\% or more of the outstanding shares. The variable excludes shares under options exercisable within 60 days, shares held in a fiduciary capacity, shares held by insurance companies, and preferred stock or debentures that are convertible into common shares.
} 


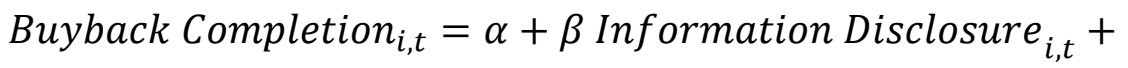
$\gamma$ CEO Overconfidence $_{i, t}+\delta$ Other CEO characteristics $_{i, t}+$

$\theta$ Firm Characteristics $_{i, t}+\varepsilon_{i, t}$

Where Buyback Completion is the percentage of actually repurchased shares relative to the number of share intended at the time of the announcement. Information Disclosure is a binary variable that takes the value of one when an announcement of the firm's intention to buy back shares contains explicit information about the intended buyback program and zero otherwise. CEO Overconfidence is a dummy variable as defined in section 2.2.1 following Malmendier et al. (2011). Other CEO Characteristics is a matrix of CEO traits as described in section 2.2.2. Firm Characteristics is a matrix of firm-specific characteristics as described in section 3.3.

Similar to other corporate finance decisions, information disclosure could be potentially endogenous. Healey and Palepu (2001) note that endogeneity is the most important limitation of capital market research on the consequences of disclosure. Although disclosure precedes the buyback transactions, it is not purely exogenous as firm characteristics that influence information disclosure might influence buyback completion rates. At the same time, CEOs might choose the information regime that is beneficial for them (Hermalin and Katz, 2000). By the same token, CEO characteristics might influence the information disclosure of a given firm. To better address this issue, we conduct an omitted variable version of Hausman's (1978) test for endogeneity of information disclosure. We follow Leone et al. (2007) and create an instrumental variable (IVInformation Disclosure) by regressing information disclosure on all exogenous variables (all the right-hand side variables in equation 1) as follows:

Information Disclosure $_{i, t}=\alpha+\gamma$ CEO Overconfidence $e_{i, t}+$ $\delta$ Other CEO characteristics $_{i, t}+\theta$ Firm Characteristics $_{i, t}+\varepsilon_{i, t}$ 
Equation 2 is estimated via a Tobit where zero and one are applied as the lower and upper limits for censoring, respectively. We then add the predicted values from regression 2 to form equation 3 .

Buyback Completion $_{i, t}=\alpha+\beta$ Information Disclosure $_{i, t}+$ $\varphi$ IV - Information Disclosure $e_{i, t}+\gamma$ CEO Overconfidence Ovi,t $_{+}$ $\delta$ Other CEO characteristics $_{i, t}+\theta$ Firm Characteristics $_{i, t}+\varepsilon_{i, t}$

Where, IV-Information Disclosure is the fitted value from regressing information disclosure on the set of all exogenous variables in the system (all right-hand variables in equation 1) via a Tobit estimation. We test whether IV-Information Disclosure is significant. If it is significant, we reject the null that information disclosure is exogenous. If it is endogenous, then we replace IV-Information Disclosure with Information Disclosure in equation 1 and estimate the equation. ${ }^{10}$

\subsection{Descriptive statistics}

Table 1 reports the average completion rates of the announced repurchase programs and the ranked percentages out of the total sample firms based on the completion rates. Moreover, Table 1 reports the average duration from the time of a buyback announcement and the first trade, measured in days. We find that almost half of the firms that intend to repurchase their shares have not done so. In addition, we find that $25 \%$ of the sample firms repurchase less than $40 \%$ of the shares targeted in the announcement and that the average completion rate for all repurchasing firms is approximately $31 \%$, similar to the completion rates reported in Ikenberry et al. (2000). However, when estimating the average completion rates for the sub-sample of those firms initiating the buyback program

\footnotetext{
${ }^{10}$ We cannot use an endogenous Tobit model, as the endogenous variable information disclosure is a binary variable.
} 
(repurchasing firms), we find that the average completion rate is $69.45 \%$, which is similar to the US completion rates of approximately $70 \%$ and $80 \%$, reported in Stephens and Weisbach (1998) and Jagannathan et al. (2000), respectively. Moreover, we find that only less than half of the share buyback announcements contain explicit information on the intended program. We also find that on average it takes 320 days for the first buyback trade. However, when considering only the repurchasing firms we find that it takes on average 51 days for the first buyback trade. The difference in the initiation lag between the overall sample and repurchasing firms shows that the firms that are most committed to buying back their shares initiate the buyback program with a very short delay.

\section{[Insert Table 1 here]}

Table 2 reports the distribution of the open market share repurchase announcements by calendar year. The majority of the announcements are located in the second half of the 10-year research period, which is consistent with the recent trend and popularity of share repurchases in the United Kingdom. In addition, we find that firms announcing their intention to conduct an open market buyback program are large, since their respective average (median) market capitalization is $11.6(1.526)$ billion GB Pounds. Moreover, we find that the average (median) market-to-book ratio is 2.87 (2.03), similar to the market-tobook ratios for repurchasing firms reported in Grullon and Michaely (2004) and Cook et al. (2004). In addition, the figures on share buybacks confirm the argument that open market share buybacks have become increasingly popular since the second half of the 1990s due to the relaxation of previously stringent regulations, consistent with v.Eije and Megginson (2008). We include year dummies to control for this time effect in our models. In 1998, the completion rate for repurchasing firms is higher than $100 \%$ of the intended amount, because repurchasing firms reserve the right to repurchase more shares than those initially disclosed provided it is within the legal authorization attained by the shareholders. 
[Insert Table 2 here]

Panel A in Table 3 reports the descriptive statistics for the firm-specific variables that have the potential to influence the completion rates of the identified buyback programs announced by the firms used in our analysis. The total number of firms identified for each variable along with the mean, median, and minimum and maximum values are reported. Our sample consists of firms with a wide range of sizes, with market capitalizations ranging from $£ 2.25$ million to $£ 233$ billion. Firms announcing their intention to buy back shares have on average excess returns of $0.6 \%$, which contradicts our predictions that repurchasing firms are more likely to be undervalued. Furthermore, firms are not highly leveraged, having an average debt ratio of $16.5 \%$ and an average ownership concentration ratio of $17.3 \%$.

In our sample, $40.1 \%$ of the firms announced their intention to conduct an open market buyback program in the past, while the completion rate among those firms of their most recent open market buyback announcement was only $19.1 \%$. Moreover, $68.7 \%$ of the firms in our sample disclose explicit information about the intended buyback program, which can be an indicator of a stronger commitment to implementing the buyback program.

\section{[Insert Table 3 here]}

The descriptive statistics presented in Panel B in Table 3 show that the average (median) CEO age is 54.31 (54) with a minimum of 31 years and a maximum of 77 years. In addition, a small percentage (1 in 11) of our sample CEOs are overconfident. The average CEO tenure is approximately 9 years, and the figures show that the CEO turnover is low in the sample companies. Average tenure in the firm is 17 years with a median of 13 years, and $29 \%$ of the CEOs are internally appointed. These figures suggest that, on average, CEOs stay with the same company for a long period and thus become very 
familiar with their firm's corporate culture and respective industry. Surprisingly, only $15 \%$ of the CEOs have business-related education, and $22 \%$ of the CEOs have a master's degree or above. However, we find that $97 \%$ of CEOs pursued a business career even though they do not have relevant degrees. Finally, $76 \%$ of the CEOs are male, and only half of the CEOs are British although our sample firms are quoted on the London Stock Exchange.

\section{The drivers of buyback completion rates}

\subsection{Univariate analysis}

To identify the firm-specific characteristics that drive the buyback completion rates, we split our sample into three groups: firms that repurchase none of their shares (no buyback trades), firms that repurchase their shares but have a completion ratio of less than the sample's average of $31.5 \%$ (partial completion), and firms that repurchase more than the average completion ratio (high completion rate). The univariate analysis reported in Table 4 shows that firms with high completion rates are on average substantially larger compared to the no-repurchasing and partial completion firms. This is in line with our expectations that large firms, which are more likely to be mature with fewer opportunities, are more likely to complete their buyback programs. In addition, we find that firms with overconfident CEOs and greater analyst coverage display significantly higher buyback completion rates. Moreover, we find that widely held firms with higher levels of cash show higher completion rates, suggesting that minority shareholders can apply more pressure on managers' decisions to follow through with the buyback program to reduce potential agency costs. In addition, we show that firms with higher completion rates have high dividend payouts, suggesting that buyback programs are used to supplement rather than substitute the existing payout policy.

[Insert Table 4 here] 
Surprisingly, we find that firms that tend to have high completion rates are highly leveraged. Furthermore, the group of firms with a high completion rate demonstrates the highest percentages in terms of the buyback repetition and completion reputation variables, with $60.6 \%$ and $44.3 \%$, respectively. The latter findings support our argument that firms that conduct more than one buyback program, have a good reputation for completing their former buyback programs, and disclose details of their current buyback program show a stronger "commitment" to successfully completing their current buyback programs that, in general, will be initiated within a shorter period. Finally, the univariate analysis shows firms that tend to repurchase shares are firms that have CEOs who have been involved with a wider network of companies. This suggests that CEOs are concerned about their reputation for keeping their "promise" to repurchase shares and complete the announced buyback program.

\subsection{Tobit estimations}

In this section, we test which factors have a significant impact on the completion rate of the announced open market buyback programs. We estimate a series of Tobit models with Completion Rate as the dependent variable, while using a number of factors discussed earlier as explanatory variables, which can potentially influence the buyback programs' completion rate. The two-tailed Tobit model accounts for the censored nature of the Completion Rate, which is naturally bounded by zero and manually truncated at one. The results from the multivariate Tobit regressions are shown in Table $5{ }^{11}$

As the first step, in column 1 we assume information disclosure is exogenous. The results for Buyback Information show that companies disclosing explicit information are likely to have higher buyback completion rates (Hypothesis 1). In addition, firms initiating

\footnotetext{
${ }^{11}$ In order to minimize the influence of outliers all continuous control variables are winsorized at the $1^{\text {st }}$ and $99^{\text {th }}$ percentiles.
} 
the intended buyback program shortly after the announcement are more likely to have high completion rates. These findings suggest that firms that disclose explicit information on the intended buyback program and have shorter buyback initiation lags are more likely to have a clear payout strategy and show a greater commitment to implementing and completing the announced program. This is consistent with Hermalin and Weisbach (2012) who show that better disclosure reduces agency problems and firms are more likely to distribute more cash.

The results for CEO Overconfidence show that the overconfidence measure is highly significant and positive. ${ }^{12}$ This suggests that overconfident CEOs are more likely to complete the announced buyback programs (Hypothesis 2). This is consistent with Malmendier and Tate (2008) who argue that overconfident CEOs overestimate their firm's value of equity and consequently are more likely to perceive their firm's share price to be undervalued. Thus, they tend to complete the intended buyback programs due to their undervaluation perception. This is also consistent with a growing body of literature showing that CEO overconfidence is related to various corporate events such as capital structure (Malmendier et al., 2011), capital budgeting (Hirshleifer et al., 2012), and acquisitions (Malmendier and Tate, 2008).

Moreover, we find that larger firms are more likely to complete their buyback programs. This is consistent with Jagannathan and Stephens (2003) who find that larger firms tend to be more frequent repurchasers. In addition, we find evidence that more widely held firms are more likely to complete their buyback programs. Regarding the impact of past buyback completion reputation, we find that it is statistically significant and

\footnotetext{
${ }^{12}$ We replicate our estimations with an alternative CEO overconfidence measure defined as a dummy variable that takes the value of one when a CEO holds options that are in the money by $67 \%$ during the last 5 years of their expiration, as in Malmendier et al. (2011). The results are qualitatively similar.
} 
positive, consistent with our expectations and Bonaimé (2012). This suggests that firms that showed their commitment in completing their former buyback programs are more likely to uphold this reputation and complete their current buybacks. In addition, we find that Excess Returns before the buyback announcement and Leverage are positively related to the buyback completion rate.

As previous research has shown that information disclosure is endogenous (Healey and Palepu, 2001), we examine whether our results are robust after controlling for potential endogeneity. We do this by conducting a Hausman (1978) version of the endogeneity test in column 2 Table 5. We first predict the variable IV-Information Disclosure by regressing information disclosure on all the explanatory variables in equation 1. We include IV-Information Disclosure along with Information Disclosure in column 2 in Table 5. Since the IV-Information Disclosure variable is significant, suggesting that information disclosure is endogenous, we use IV-Information Disclosure instead of Information Disclosure in all remaining equations.

After controlling for endogeneity, consistent with our previous findings, the results show that CEO Overconfidence is positive and significantly related to buyback completion rates which is consistent with Hypothesis 2 (column 3 Table 5). This implies that overconfident CEOs perceive their shares to be undervalued leading to higher buyback completion rates. Our results for Buyback Information (Hypothesis 1) and Buyback Reputation still hold, i.e., have a significant and positive impact on buyback completion rates. Moreover, Initiation Lag is still negative and significant suggesting that the sooner firms start their buyback program the more likely they are to complete it. We find that Market-to-Book is positively related with the buyback completion rate, suggesting that firms that tend to complete the announced buyback programs are firms that have high growth, consistent with Jagannathan and Stephens (2003) and Bonaimé (2012). 
[Insert Table 5 here]

In column 4, Table 5, we enter CEO Overconfidence and all other CEO traits but not Information Disclosure and the other variables, to assess the individual impact of CEO traits on buyback completion rates. This is to address the issue that CEOs might choose the information environment (Hermalin and Katz, 2000) and therefore CEO characteristics might influence information disclosure. As expected and consistent with our findings, CEO Overconfidence is still positive and economically significant. The results on other CEO characteristics show that Age and Business Education are positively related to buyback completions. This is consistent with our expectations, suggesting that older CEOs have a better understanding of the firm's fundamentals and their shareholders' requirements, carrying out their promise to buy back shares and complete the respective buyback program (Hypothesis 3).

Moreover, we find consistent with our expectations that CEOs with longer tenure and therefore greater entrenchment are less likely to complete the buyback program. This suggests that CEOs with longer tenure become more entrenched and strengthen their influence over the board, which enables them to resist discipline-imposing mechanisms such as share buyback programs. This is consistent with Hill and Phan (1991) who find that tenure provides CEOs with greater ability to avoid monitoring and incentive alignment mechanisms, such as, in this case, share buybacks. In contrast, board connectedness as measured with the Number of Directorships Held is positively related to the buyback completion rate. This shows that CEOs with a high degree of connectedness consider it is in their best interest to uphold their reputation for fulfilling their promises for making payouts and completing the respective buyback programs. In column 5, Table 5 we include the IV-Information Disclosure variable but not the other firm-specific control variables. Our results remain qualitatively the same, and thus, our findings are robust. 
In the last column in Table 5, we include all the variables in the same equation. Our results remain unaltered. In sum, we find that CEO Overconfidence and Information Disclosure are positively related to the buyback completion rate. We also find that past Excess Returns are positive and Ownership Concentration is negatively related to the buyback completion rate. Finally, CEO Age and Number of Directorships remain significant after controlling for other factors.

\section{Robustness checks}

For checking the robustness of our results, we partition our initial sample into firms that disclose explicit information on the intended buyback program and firms that do not. The results in Table 6 show that our main results are driven by firms that disclose explicit information on their buyback programs. We find that CEO Overconfidence is positive and Initiation Lag is negatively related to buyback completion rates. We also find that Marketto-Book, Excess Returns, and CEO Tenure have a positive impact, whereas Ownership Concentration and Dividend Payout have a negative impact on buyback completion rates. This confirms our expectations that information disclosure is related to a higher commitment to follow through with the announced buyback program.

We also partition our sample based on repetitions of buyback programs. Our main results are driven by firms that conduct more than one share buyback program. $I V$-Buyback Information is significant and positive, and Initiation Lag is negative and significant, consistent with our previous results. Market-to-Book, Excess Returns, and Leverage are positive and significant. In contrast, Ownership Concentration and Dividend Payout are negative and significant.

\section{[Insert Table 6 here]}

Moreover, we examine the determinants of information disclosure as it is interesting on its own virtue and to accommodate the endogeneity of disclosure in our buyback 
completion analysis. Existing literature argues that firm-specific characteristics could influence information disclosure. For example, larger and widely held firms followed by numerous analysts might disclose more information (Brockman et al., 2008). At the same time, CEOs might choose the information regime (Hermalin and Katz, 2000). We perform logit regressions with Buyback Information as the dependent variable, to identify which characteristics drive firms to announce explicit information about their intended buyback programs. We also include the CEO characteristics since they might influence the information environment. The results reported in Table 7 show that CEO Overconfidence is positively related to Information Disclosure, which implies that overconfident managers provide more information about their intention to buy back shares. We find that larger companies provide more disclosure. We also find that Buyback Repetition is negatively related to Buyback Information, which implies that companies that repeat buyback programs disclose less information. However, Number of Analysts is not significant, implying that firms' information environment does not affect information disclosure regarding buyback programs after controlling all other factors. In addition, we find that firms that have British nationals as CEOs and CEOs with business education are more likely to provide more information regarding their share buyback programs.

[Insert Table 7 here]

Finally, we examine the impact of firm-specific and CEO characteristics on buyback completion rates while actively considering the impact of time. We do this by using a hazard model in which the dependent variable is a binary variable equal to one if the company has followed through with its buyback program and zero if the company has not made any buyback trades. The time variable we use is the initiation lag in days, since it is a highly significant determinant of buyback completion.

[Insert Table 8 here] 
The results presented in Table 8 are similar for the two equations and show that Ownership Concentration is negatively related to the completion rate (hazard ratio of 0.986). This suggests that firms with higher agency problems are less likely to complete their buyback program. The Buyback Repetition dummy, Completion Reputation, and Buyback Information Disclosure are highly significant and positively related to the buyback completion rate as they have a hazard ratio higher than 1 . In addition, we find that longer CEO tenure is positively related to a higher buyback completion rate. In conclusion, our findings are robust across varying specifications, and the disclosure on the intended buyback program, CEO Overconfidence, Buyback Repetition, and Completion Reputation have a significant and positive impact on buyback completion rates. In sum, the results from the hazard models are qualitatively similar to the results from the Tobit models.

\section{Summary and conclusion}

The goal of this study is to assess whether the choice of disclosing explicit information or not on the intended share buyback program and CEO overconfidence among other characteristics explain share buyback completion rates. We show that disclosing explicit information about the intended buyback program can serve as a strong signal of a firm's intentions to complete the intended buyback program. In addition, we show that CEO characteristics have a strong impact on completing a share buyback program. In particular, we find robust evidence that overconfident CEOs are significantly more likely to complete the intended buybacks. We also find that firms initiating their buyback program soon after the announcement and those conducting repeat buyback programs are more likely to complete their current buyback program. In addition, we find that CEO age, connectedness, and firm tenure are positively related to the buyback completion rate. 
We also consider that information disclosure could be endogenous, as firm-specific and CEO-specific characteristics could influence the information environment. We control for endogeneity by using a two-stage Tobit regression, and our findings remain robust and are not driven by endogeneity. Since we argue that information disclosure is endogenous, we examine the determinants of information disclosure. We find that overconfident CEOs disclose more information and firms that have a shorter initiation lag are more likely to disclose explicit information on their intended buyback program.

In addition, we undertake further robustness checks. First, we split our samples into firms that disclose explicit information and those that do not, and our findings hold. Second, we split our sample into firms that conduct more than one buyback program and those that do not during our sample period, and our results remain qualitatively similar. Finally, we use a hazard model estimation where the initiation lag serves as the time variable, and our findings still hold. In sum, our results survive a battery of robustness checks. However, we do not assess whether managerial miscalibration (in Ben-David et al., 2012) affects share buyback completion rates, which could be an area for further research. 


\section{References}

Andriosopoulos, D., Hoque, H., 2013. The determinants of share repurchases in Europe. International Review of Financial Analysis, forthcoming.

Agarwal, S., Driscoll, J., Gabaix, X., Laibson, D., 2007. The age of reason: Financial decisions over the life cycle. Working paper, New York University.

Babenko, I., Tserlukevich, Y., Vedrashko, A., 2012. The credibility of open market share repurchase signaling. Journal of Financial and Quantitative Analysis 47, 1059-1088.

Banyi, M.L., Dyl, A.E., Kahle, M.K., 2008. Errors in estimating share repurchases. Journal of Corporate Finance 14, 460-474.

Barber, B., Odean, T., 2001. Boys will be boys: Gender, overconfidence, and common stock investment. Quarterly Journal of Economics 116, 261-292.

Bargeron, L., Kulchania, M., Thomas, S., 2011. Accelerated share repurchases. Journal of Financial Economics 101, 69-89.

Bhattacharya, U., Dittmar, A., 2003. Costless versus costly signalling: Theory and evidence from share repurchasing. Kelley School of Business Working Paper.

Ben-David, I., Graham, J., Harvey, C., 2012. Managerial overconfidence and corporate policies. Dice Center Working Paper 2010-12.

Beyer A., Cohen, D.A., Lys, T.Z., Walther, B.R., 2010. The financial reporting environment: Review of the recent literature. Journal of Accounting and Economics, 50, 296-343.

Bonaimé, A.A., 2012. Repurchases, reputation, and returns. Journal of Financial and Quantitative Analysis 47, 469-491.

Botosan, C., 1997. Disclosure level and the cost of equity capital. Accounting Review 72, 323-349. 
Brockman, P., Chung, D.Y., 2001. Managerial timing and corporate liquidity: Evidence from actual share repurchases. Journal of Financial Economics 61, 417-448.

Brockman, P., Khurana, I.K., Martin, X., 2008, Voluntary disclosures and share repurchases. Journal of Financial Economics 89, 175-191.

Chan, K., Ikenberry, D., Lee, I., 2004. Economic sources of gain in stock repurchases. Journal of Financial and Quantitative Analysis 39, 461-479.

Chan, K., Ikenberry, D., Lee, I., 2007. Do managers time the market? Evidence from openmarket share repurchases. Journal of Banking and Finance 31, 2673-2694.

Chan, K., Ikenberry, D.L., Lee, I., Wang, Y., 2010. Share repurchases as a potential tool to mislead investors. Journal of Corporate Finance 16, 137-158.

Chevalier, J., Ellison, G., 1999. Are some mutual fund managers better than others? Crosssectional patterns in behavior and performance. Journal of Finance 54, 875-899.

Cook, D.O., Krigman, L., Leach, C.J., 2004. On the timing and execution of open market repurchases. Review of Financial Studies 17, 463-498.

Cronqvist, H.F., Makhija, A., Yonker, S., 2012. Behavioral consistency in corporate finance: CEO Personal and Corporate Leverage. Journal of Financial Economics $103,20-40$.

Dittmar, A.K., 2000. Why do firms repurchase stock? Journal of Business 73, 331-355.

Easterbrook, F.H., 1984. Two agency-cost explanations of dividends. American Economic Review 74, 650-659.

Eije v., H., Megginson, W.L., 2008. Dividends and share repurchases in the European Union. Journal of Financial Economics 89, 347-374.

Fama, E.F., French, K.R., 2001. Disappearing dividends: Changing firm characteristics or lower propensity to pay? Journal of Applied Corporate Finance 14, 67-79. 
Ferris, S.P., Jayaraman, N., Sabherwal, S., 2013. CEO overconfidence and international merger and acquisition activity. Journal of Quantitative and Financial Analysis, forthcoming.

Fracassi, C., 2008. Corporate finance policies and social networks. Working paper, University of Texas at Austin.

Fracassi, C., Tate, G., 2012. External networking and internal firm governance. Journal of Finance 67, 153-194.

Frank, M.Z., Goyal, V.K., 2007. Corporate leverage: How much do managers really matter? Working paper, available at: http://papers.ssrn.com/sol3/papers.cfm?abstract_id=971082

Ginglinger, E., Hamon, J., 2007. Actual share repurchases, timing and liquidity. Journal of Banking \& Finance 31, 915-938.

Grullon, G., Michaely, R., 2002. Dividends, share repurchases, and the substitution hypothesis. Journal of Finance 57, 1649-1684.

Grullon, G., Michaely, R., 2004. The information content of share repurchase programs. Journal of Finance 59, 651-680.

Grullon, G., Michaely, R., Swaminathan, B., 2002. Are dividend changes a sign of firm maturity? Journal of Business 75, 387-424.

Guay, W., Harford, J., 2000. The cash-flow permanence and information content of dividend increases versus repurchases. Journal of Financial Economics 57, 385-415.

Guner, A.B., Malmendier, U., Tate, G., 2008. Financial expertise of directors. Journal of Financial Economics 88, 323-354.

Hackbarth, D., 2008. Managerial traits and capital structure decisions. Journal of Financial and Quantitative Analysis, 43, 843-881.

Hausman, J. 1978. Specification Tests in Econometrics. Econometrica 46, 1251-71. 
Healy, P., Hutton, A., Palepu, K., 1999. Stock performance and intermediation changes surrounding sustained increases in disclosure. Contemporary Accounting Research $16,485-520$.

Healy, P., Palepu, K., 2001. Information Asymmetry, Corporate Disclosure, and the Capital Markets: A Review of the Empirical Disclosure Literature. Journal of Accounting and Economics 31, 405-40.

Hermalin, B.E., Katz, M.L., 2000. Corporate diversification and agency. In: Hammond, P.J., Myles, G.D. (Eds.), Incentives, Organization, and Public Economics: Papers in Honour of Sir James Mirrlees. Oxford University Press, Oxford.

Hermalin, B.E., Weisbach, M.S., 1998. Endogenously chosen boards of directors and their monitoring of the CEO. American Economic Review 88, 96-118.

Hermalin, B.E., Weisbach, M.S., 2012. Information disclosure and corporate governance. Journal of Finance 67, 195-234.

Hill, C.W.L., Phan, P., 1991. CEO tenure as a determinant of CEO pay. Academy of Management Journal 34, 707-17.

Hirshleifer, D., Low, A., Teoh, S.H., 2012. Are overconfident CEOs better innovators? Journal of Finance, 67, 1457-1498.

Hochberg, V.Y., Ljungqvist, A., Lu, Y., 2007. Whom you know matters: Venture capital networks and investment performance. Journal of Finance 62, 251-301.

Hwang, B.H., Kim, S., 2009. It pays to have friends. Journal of Financial Economics 93, 138-158.

Ikenberry, D., Lakonishok, J., Vermaelen, T., 1995. Market underreaction to open market share repurchases. Journal of Financial Economics 39, 181-208.

Ikenberry, D., Lakonishok, J., Vermaelen, T., 2000. Stock repurchases in Canada: Performance and strategic trading. Journal of Finance 55, 2373-2397. 
Ikenberry D., Vermaelen, T., 1996. The option to repurchase stock. Financial Management, 25, 9-24.

Jagannathan, M., Stephens, C., 2003. Motives for multiple open-market repurchase programs. Journal of the Financial Management Association 32, 71-91.

Jagannathan, M., Stephens, C.P., Weisbach, M.S., 2000. Financial flexibility and the choice between dividends and stock repurchases. Journal of Financial Economics 57, $355-384$.

Jensen, M.C., 1986. Agency costs of free cash flow, corporate finance, and takeovers. American Economic Review 76, 323.

Jensen, M.C., Murphy, K., Wruck, E.G., 2004. Remuneration: Where we've been, how we got to here, what are the problems, and how to fix them. Harvard NOM Working paper No. 04-28; ECGI - Finance Working paper No. 44/2004.

Kim, J., Varaiya, N., Schremper, R., 2004. Survey on open market repurchase regulations: cross-country examination of the ten largest stock markets. San Diego State University Working Paper.

Leone, A.J., Rock, S., Willenborg, M., 2007. Disclosure of intended use of proceeds and underpricing of initial public offerings. Journal of Accounting Research 45, 111-153.

Leuz, C., Verrecchia, R., 2000. The economic consequences of increased disclosure. Journal of Accounting Research 38, 91-136.

Malmendier, U., Tate, G.A., 2005. CEO overconfidence and corporate investment. Journal of Finance 60, 2661-2700.

Malmendier, U., Tate, G.A., 2008. Who makes acquisitions? CEO overconfidence and the market's reaction. Journal of Financial Economics 89, 20-43. 
Malmendier, U., Tate, G., Yan, J., 2011. Overconfidence and early-life experiences: The effect of managerial traits on corporate financial policies. Journal of Finance 66, 1687-1733.

Masulis, W.M., Mobbs, S., 2011. Are all inside directors the same? Evidence from the external directorship market. Journal of Finance 66, 823-872.

McNally, W.J., 1999. Open market stock repurchase signaling. Journal of the Financial Management Association 28, 55-67.

Mitchell, J.D., Dharmawan, G.V., 2007. Incentives for on-market buy-backs: Evidence from a transparent buy-back regime. Journal of Corporate Finance 13, 146-169.

Morck, R., Shleifer, A., Vishny, R., 1988. Management ownership and market valuation: An empirical analysis. Journal of Financial Economics 20, 293-316.

Ofek, E., Yermack, D., 2000. Taking stock: Equity-based compensation and the evolution of managerial ownership. Journal of Finance 55, 1367-1384.

Oswald, D., Young, S., 2004. What role taxes and regulation? A second look at open market share buyback activity in the UK. Journal of Business Finance and Accounting 31, 257-292.

Oswald, D., Young, S., 2008. Share reacquisitions, surplus cash, and agency problems. Journal of Banking and Finance 32, 795-806.

Petersen, M.A., 2009. Estimating standard errors in finance panel data sets: Comparing approaches. Review of Financial Studies 22, 435-480.

Rau, P.R., Vermaelen, T., 2002. Regulation, taxes, and share repurchases in the United Kingdom. Journal of Business 75, 245-282.

Shefrin, H., 2005. A Behavioral Approach to Asset Pricing. Academic Press Advanced Finance Series, London, United Kingdom. 
Shleifer A., Vishny, R., 1997. A survey of corporate governance. Journal of Finance 52, 737-783.

Song, F., Thakor, A.V., 2006. Information control, career concerns, and corporate governance. Journal of Finance 61, 1845-1896.

Stephens, C.P., Weisbach, M.S., 1998. Actual share reacquisitions in open-market repurchase programs. Journal of Finance 53, 313-333.

Vermaelen, T., 1981. Common stock repurchases and market signalling. Journal of Financial Economics 9, 139-183.

Verrecchia, R., 2001. Essays on disclosure. Journal of Accounting \& Economics 32, 97180.

Yim, S., 2013. The acquisitiveness of youth: CEO age and acquisition behavior. Journal of Financial Economics. Available at: http://dx.doi.org/10.1016/j.jfineco.2012.11.003i. Zhang, H., 2005. Share price performance following actual share repurchases. Journal of Banking and Finance 29, 1887-1901. 
Table 1

Share repurchase completion rates in the United Kingdom.

Repurchasing

No.

181

219

400

126

274

400

Total

Buyback Information

No Buyback Information

219

54.75

0

$0.1-20 \%$

21-40\%

$41-60 \%$

61-80\%

$>81 \%$

Total

Difference in days of initiation
Entire sample
Repurchasing firms

\section{Completion ratio}

Entire sample

Repurchasing firms
64

16.00

36

9.00

18

4.50

17

4.25

46

11.50

400

$100 \%$

$\underline{\text { Mean }}$

$\underline{\text { Median }}$

319.35

547

51.10

8

Notes: This table reports the number and percentage of firms that have actually repurchased their shares (Repurchasing firms) and those that have not repurchased any of their shares (Non-Repurchasing firms) for 1997 to 2006. Additionally, the table reports the number of firms that disclosed explicit information about their intended buybacks (Buyback information) and those firms that did not disclose any information (No Buyback information). Furthermore, the table reports the distribution of buyback activity. Finally, the table reports the statistics for the completion rates and the number of days from the day of the announcement to the day of initiation of the announced share repurchase programs, for the entire sample of announced buyback programs and sub-sample of repurchasing firms (Repurchasing firms). 
Table 2

Yearly distribution of firm characteristics and their completion rates.

\begin{tabular}{|c|c|c|c|c|c|c|c|}
\hline Year & No. & $\begin{array}{l}(\%) \text { of } \\
\text { total } \\
\text { sample }\end{array}$ & $\begin{array}{c}\text { Completion rates }(\%) \\
\text { (total sample) }\end{array}$ & No. & $\begin{array}{c}\text { Completion rates }(\%) \\
\text { (repurchasing firms) }\end{array}$ & Market-to-Book & $\begin{array}{l}\text { Market capitalization } \\
\text { (millions of GBP) }\end{array}$ \\
\hline
\end{tabular}

\begin{tabular}{cccccccccccc}
\hline & & & Mean & Median & & Mean & Median & Mean & Median & Mean & Median \\
\hline 1997 & 15 & $4 \%$ & 53.83 & 3.70 & 8 & 100.93 & 43.01 & 1.859 & 1.534 & 10,100 & 3,868 \\
1998 & 34 & $9 \%$ & 56.20 & 0.00 & 14 & 136.49 & 32.14 & 2.645 & 2.025 & 12,700 & 937 \\
1999 & 21 & $5 \%$ & 12.39 & 0.00 & 6 & 43.37 & 35.75 & 2.386 & 0.945 & 8,988 & 461 \\
2000 & 22 & $6 \%$ & 26.06 & 0.00 & 9 & 63.70 & 80.06 & 2.492 & 1.632 & 12,000 & 851 \\
2001 & 37 & $9 \%$ & 19.52 & 2.12 & 19 & 38.02 & 27.05 & 3.048 & 2.223 & 7,275 & 1,180 \\
2002 & 51 & $13 \%$ & 27.65 & 4.39 & 27 & 52.23 & 28.76 & 3.492 & 3.077 & 17,100 & 1,599 \\
2003 & 41 & $10 \%$ & 18.02 & 0.00 & 18 & 41.04 & 18.40 & 2.832 & 2.122 & 6,201 & 1,068 \\
2004 & 56 & $14 \%$ & 30.70 & 0.00 & 24 & 71.63 & 48.07 & 2.825 & 1.806 & 10,900 & 1,644 \\
2005 & 65 & $16 \%$ & 30.82 & 0.00 & 28 & 71.55 & 47.94 & 2.658 & 1.451 & 12,400 & 1,586 \\
2006 & 58 & $15 \%$ & 41.80 & 0.00 & 28 & 86.59 & 27.12 & 3.176 & 2.225 & 13,100 & 2,202 \\
& & & & & & & & & & & \\
Total & 400 & $100 \%$ & $31.43 \%$ & $0.00 \%$ & 181 & $69.45 \%$ & $33.77 \%$ & 2.874 & 2.027 & 11,600 & 1,526 \\
\hline
\end{tabular}

Notes: This table reports the annual distribution of share repurchase announcements and the completion rates of the respective announcements of the overall sample for 1997 to 2006. In addition, the table reports the average and median values per annum of the completion rates of the intended amount targeted at the time of the repurchase announcement and the respective values (at the beginning of the year before the announcement) of size proxied by the market capitalization, and valuation proxied by the market-to-book ratio. 
Table 3

Descriptive statistics.

\begin{tabular}{|c|c|c|c|c|c|}
\hline Panel A. Firm-specific variables & $\mathrm{N}$ & Mean & Median & Min & $\operatorname{Max}$ \\
\hline Completion rate (\%) & 400 & 31.5 & 0 & 0 & 13.81 \\
\hline Information disclosure & 400 & 0.69 & 1 & 0 & 1 \\
\hline Initiation lag days & 400 & 319.35 & 547 & 0 & 547 \\
\hline Buyback reputation & 400 & 0.19 & 0 & 0 & 5.26 \\
\hline Buyback repetition & 400 & 0.4 & 0 & 0 & 1 \\
\hline Size (millions of GBP) & 358 & 11,600 & 1,526 & 2.25 & 233,000 \\
\hline Market-to-book & 358 & 2.87 & 2.03 & 0.62 & 7.09 \\
\hline Excess returns & 373 & 0.01 & 0 & -0.22 & 0.23 \\
\hline Leverage & 364 & 0.17 & 0.12 & 0 & 0.79 \\
\hline Options (\%) & 318 & 0.03 & 0.00 & 0.00 & 1.84 \\
\hline Convertible debt (\%) & 318 & 0.62 & 0.00 & 0.00 & 87.59 \\
\hline No. of analysts & 400 & 11.31 & 11.00 & 0.00 & 47.00 \\
\hline Standard deviation & 373 & 0.02 & 0.02 & 0.00 & 0.18 \\
\hline Cash & 333 & 0.15 & 0.14 & -1.15 & 0.65 \\
\hline Ownership concentration & 340 & 17.31 & 13.11 & 0 & 91.63 \\
\hline Dividend payout & 303 & 37.39 & 37.67 & 0 & 95.57 \\
\hline Dividend yield & 358 & 3.12 & 3.05 & 0 & 9.83 \\
\hline \multicolumn{6}{|l|}{ Panel B. CEO traits } \\
\hline CEO overconfidence & 400 & 0.11 & 0 & 0 & 1 \\
\hline CEO age & 302 & 54.31 & 54 & 31 & 77 \\
\hline CEO tenure & 310 & 8.88 & 8 & 1 & 40 \\
\hline Tenure in the firm & 306 & 16.56 & 13 & 1 & 42 \\
\hline Number of companies worked for & 294 & 2.34 & 2 & 0 & 11 \\
\hline Number of directorships held & 300 & 6.57 & 7 & 0 & 17 \\
\hline Founder & 395 & 0.37 & 0 & 0 & 1 \\
\hline Internally & 396 & 0.29 & 0 & 0 & 1 \\
\hline Business education & 396 & 0.15 & 0 & 0 & 1 \\
\hline Highest education & 396 & 0.22 & 0 & 0 & 1 \\
\hline Business or non-business career & 396 & 0.97 & 1 & 0 & 1 \\
\hline Gender & 397 & 0.76 & 1 & 0 & 1 \\
\hline Nationality & 397 & 0.55 & 1 & 0 & 1 \\
\hline
\end{tabular}


Notes: This table presents the descriptive statistics for the variables used in this study. Panel A presents the firm-specific characteristics, and Panel B presents the CEO related variables. Completion Rate is the percentage of the repurchased shares relative to the amount targeted at the time of the announcement, where the amount targeted is explicitly stated as the total number of shares. Alternatively, the targeted number of shares is extrapolated by the firms' market value with the current price at the time of announcement (when the target percentage of shares to be repurchased is stated) or extrapolated from the relative value of the shares at the time of the announcement (when an explicit monetary value is disclosed in the announcement). Information Disclosure takes the value of one when an announcement of the intention to buy back shares contains explicit information about the intended buyback program and zero when no information is disclosed. Initiation lag is the number of days from the day of the announcement to the initiation of the repurchase program. Buyback reputation is the completion rate of the most recent buyback program implemented by firm $i$. Buyback repetition is a dummy variable that takes the value of one if a firm has announced its intention to buy back its shares in the past, during the ten-year period under study, and zero otherwise. Size is the market capitalization for firm $i$ at the year-end before the announcement of the intention to buy back shares and reported in millions of GB pounds. Market to-Book is the ratio of market value for each company $i$ to its respective book value of assets at the year-end before the announcement of the intention to buy back shares. Excess returns is the cumulative excess return of firm $i$ relative to the FTSE All Share index for the period of 22 to 2 days before the announcement. Leverage is the ratio of long-term debt to the book value of total assets of firm i at the year-end before the announcement of the intention to buy back shares. Options is the value (in GB pounds) of all options exercised scaled my market capitalization of firm $i$ at the year-end before the announcement of the intention to buy back shares. Convertible debt is the value of convertible debt outstanding (in GB pounds) of firm $i$ at the year-end before the announcement of the intention to buy back shares. Number of analysts is the number of analyst recommendations of firm $i$ at the year-end before the announcement of the intention to buy back shares. Standard deviation is the 200-day standard deviation of daily returns for the time period -210 to -10 days for firm $i$ before the buyback announcement. Cash is the ratio of net income before taxes plus depreciation and changes in deferred taxes and other deferred charges to total assets for firm $i$ before the buyback announcement. Ownership concentration is the percentage of closely held shares divided by the number of total common shares outstanding at the year-end before the repurchase announcement. Dividend payout is the ratio of common cash dividends relative to the reported net income for each firm $i$ at the yearend before the open market share repurchase announcement. Dividend yield is the ratio of dividends paid relative to the share price, for each firm $i$ at the yearend before the repurchase announcement. CEO Overconfidence is a dummy variable that takes the value of one for those CEOs who at any point during the sample period, hold an option until the year of expiration even though the option is at least $40 \%$ in the money entering its final year. Gender is a dummy equal to one if the CEO is male and zero otherwise. Nationality is a dummy variable equal to one if the CEO has a British citizenship and zero otherwise. CEO Age is the difference between the date of birth and the end of 2011 expressed in years. Founder is a dummy variable that takes the value of one if the CEO is the firm's founder and zero otherwise. CEO Tenure is the difference between joining date as CEO and ending in 2011, expressed in years. Tenure in the firm is the number of years employed by the company. Internally is a dummy variable equal to one if the CEO was appointed internally and zero otherwise. Number of companies worked for is the number of companies the CEO has worked as a director. Number of directorships held is the number of companies in which the CEO is serving as director at the time. Business education is a dummy variable equal to one if the CEO has received a business education and zero otherwise. 
Table 4

Univariate sorting on completion rate.

\begin{tabular}{|c|c|c|c|c|c|c|c|c|c|c|c|}
\hline \multirow[b]{2}{*}{ Variables } & \multicolumn{3}{|c|}{ No buyback trades } & \multicolumn{3}{|c|}{ Partial completion rate } & \multicolumn{3}{|c|}{ High completion rate } & \multirow{2}{*}{$\begin{array}{l}\text { Homogeneity } \\
\text { across means }\end{array}$} & \multirow{2}{*}{$\begin{array}{l}\text { Homogeneity } \\
\text { across medians }\end{array}$} \\
\hline & $\mathrm{N}$ & Mean & Median & $\mathrm{N}$ & Mean & Median & $\mathrm{N}$ & Mean & Median & & \\
\hline Information disclosure & 218 & 0.619 & 1 & 87 & 0.609 & 1 & 94 & 0.915 & 1 & $(0.000)^{* * *}$ & $(0.001)^{* * *}$ \\
\hline Initiation lag (days) & 218 & 542.07 & 547 & 87 & 75.17 & 19 & 94 & 28.83 & 6 & $(0.000)^{* * *}$ & $(0.000)^{* * *}$ \\
\hline Buyback reputation & 218 & 0.055 & 0 & 87 & 0.258 & 0 & 94 & 0.443 & 0 & $(0.000)^{* * *}$ & $(0.000)^{* * *}$ \\
\hline Buyback repetition & 218 & 0.257 & 0 & 87 & 0.54 & 1 & 94 & 0.606 & 1 & $(0.000)^{* * *}$ & $(0.000)^{* * *}$ \\
\hline Size (millions of GBP) & 182 & 7,763 & 647 & 83 & 9,577 & 1,561 & 93 & 20,700 & 2,229 & $(0.012)^{* *}$ & $(0.000)^{* * *}$ \\
\hline Market-to-book & 182 & 2.501 & 1.718 & 83 & 3.314 & 2.712 & 93 & 3.212 & 2.315 & $(0.697)$ & $(0.000)^{* * *}$ \\
\hline Excess returns & 196 & 0.001 & -0.007 & 83 & 0.004 & 0.002 & 94 & 0.019 & 0.017 & $(0.529)$ & $(0.601)$ \\
\hline Leverage & 188 & 0.14 & 0.093 & 83 & 0.18 & 0.171 & 93 & 0.201 & 0.177 & $(0.008)^{* * *}$ & $(0.193)$ \\
\hline Options \% & 219 & 0.005 & 0 & 87 & 0.010 & 0 & 94 & 0.050 & 0 & $(0.456)$ & $(0.544)$ \\
\hline Convertible debt $\%$ & 219 & 0.500 & 0 & 87 & 0.200 & 0 & 94 & 1.200 & 0 & $(0.388)$ & $(0.416)$ \\
\hline No. of analysts & 219 & 8.105 & 6 & 87 & 12.897 & 13 & 94 & 17.287 & 17 & $(0.000)^{* * * *}$ & $(0.000)^{* * *}$ \\
\hline Standard deviation & 193 & 0.025 & 0.019 & 86 & 0.018 & 0.016 & 94 & 0.015 & 0.013 & $(0.000)^{* * *}$ & $(0.000)^{* * *}$ \\
\hline Cash & 177 & 0.143 & 0.138 & 76 & 0.178 & 0.169 & 80 & 0.130 & 0.110 & $(0.079)^{*}$ & $(0.003)^{* * *}$ \\
\hline Ownership concentration & 166 & 21.83 & 19.385 & 82 & 12.675 & 10.809 & 92 & 13.289 & 5.231 & $(0.000)^{* * *}$ & $(0.002)^{* * *}$ \\
\hline Dividend payout & 159 & 32.349 & 30.53 & 73 & 43.028 & 41.658 & 71 & 42.89 & 41.842 & $(0.000)^{* * *}$ & $(0.005)^{* * *}$ \\
\hline Dividend yield & 182 & 3.078 & 2.958 & 83 & 2.975 & 3.152 & 93 & 3.331 & 3.175 & $(0.374)$ & $(0.817)$ \\
\hline CEO overconfidence & 219 & 0.064 & 0 & 87 & 0.069 & 0 & 94 & 0.255 & 0 & $(0.000)^{* * *}$ & $(0.000)^{* * *}$ \\
\hline Gender & 219 & 0.658 & 1 & 87 & 0.885 & 1 & 94 & 0.904 & 1 & $(0.000)^{* * *}$ & $(0.017)^{* *}$ \\
\hline Nationality & 219 & 0.457 & 0 & 87 & 0.632 & 1 & 94 & 0.713 & 1 & $(0.000)^{* * *}$ & $(0.012)^{* *}$ \\
\hline CEO age & 138 & 3.971 & 3.990 & 77 & 3.988 & 3.990 & 87 & 3.998 & 3.990 & $(0.392)$ & $(0.994)$ \\
\hline Founder & 216 & 0.491 & 0 & 87 & 0.218 & 0 & 94 & 0.223 & 0 & $(0.000)^{* * *}$ & $(0.230)$ \\
\hline CEO tenure & 147 & 2.043 & 2.080 & 75 & 1.939 & 2.080 & 88 & 2.005 & 1.950 & $(0.540)$ & $(0.340)$ \\
\hline Tenure in the firm & 142 & 2.656 & 2.710 & 77 & 2.475 & 2.480 & 87 & 2.565 & 2.560 & $(0.162)$ & $(0.090)^{*}$ \\
\hline Internally & 216 & 0.264 & 0 & 87 & 0.287 & 0 & 94 & 0.362 & 0 & $(0.243)$ & $(0.362)$ \\
\hline Number of companies worked for & 216 & 0.621 & 0.000 & 87 & 0.941 & 1.100 & 94 & 0.926 & 1.100 & $(0.000)^{* * *}$ & $(0.000)^{* * *}$ \\
\hline Number of directorships held & 124 & 1.753 & 1.950 & 67 & 1.797 & 2.080 & 80 & 1.842 & 1.950 & $(0.679)$ & $(0.771)$ \\
\hline Business education & 216 & 0.116 & 0 & 87 & 0.161 & 0 & 94 & 0.213 & 0 & $(0.108)$ & $(0.259)$ \\
\hline
\end{tabular}

Notes: The table reports the descriptive statistics for the three sub-groups of firms with Completion Rate $=0$, Completion Rate $>0 \leq 31.5 \%$, and Completion Rate $>31.5 \%$. Completion Rate is the percentage of the repurchased shares relative to the amount targeted at the time of the announcement. The variables are defined as in Table 3 and all continuous control variables are winsorized at the $1^{\text {st }}$ and $99^{\text {th }}$ percentiles. Homogeneity, reports the $p$-values based on $\chi^{2}$ and Pearson's continuity correction $\chi^{2}$ for the homogeneity test of means, and medians, respectively, across the three sub-groups of firms with no buyback trades $($ Completion Rate $=0 \%)$, partial completion rate (Completion Rate $>0 \leq 31.5 \%)$, and high completion rate (Completion Rate $>31.5 \%)$. 
${ }^{*}$ Statistical significance at the $10 \%$ level.

Statistical significance at the $5 \%$ level.

${ }^{* * * *}$ Statistical significance at the $1 \%$ level. 
Table 5

Tobit regressions on the drivers of buyback completion rates.

\begin{tabular}{|c|c|c|c|c|c|c|c|c|c|c|c|c|}
\hline & \multicolumn{2}{|c|}{ (1) } & \multicolumn{2}{|c|}{ (2) } & \multicolumn{2}{|c|}{ (3) } & \multicolumn{2}{|c|}{ (4) } & \multicolumn{2}{|c|}{ (5) } & \multicolumn{2}{|c|}{ (6) } \\
\hline & Coef. & $t$-stat & Coef. & $t$-stat & Coef. & $t$-stat & Coef. & $t$-stat & Coef. & $t$-stat & Coef. & $t$-stat \\
\hline Cons & 0.195 & $(0.39)$ & -0.468 & $(-0.80)$ & -0.597 & $(-0.99)$ & -2.323 & $(-1.58)$ & -0.889 & $(-0.63)$ & $-3.889^{* * *}$ & $(-2.55)$ \\
\hline CEO overconfidence & $0.528^{* * *}$ & $(3.05)$ & $0.636^{* * *}$ & $(4.14)$ & $0.620^{* * *}$ & $(3.94)$ & $0.601^{* * *}$ & $(3.45)$ & $0.550^{* * *}$ & $(2.86)$ & $0.616^{* * *}$ & $(3.46)$ \\
\hline Information disclosure & $0.411^{* * *}$ & $(4.70)$ & $0.386^{* * *}$ & $(4.42)$ & & & & & & & & \\
\hline IV-Information disclosure & & & $0.858^{*}$ & $(1.86)$ & $1.369^{* * *}$ & $(2.81)$ & & & $1.288^{* * *}$ & $(4.14)$ & $0.493^{* * *}$ & $(5.58)$ \\
\hline Initiation lag & $-0.206^{* * * *}$ & $(-7.68)$ & $-0.175^{* * *}$ & $(-6.58)$ & $-0.169^{* * *}$ & $(-6.27)$ & & & & & $-0.157^{* * *}$ & $(-6.75)$ \\
\hline Buyback reputation & $0.269^{* * *}$ & $(2.59)$ & $0.560^{* * *}$ & $(5.36)$ & $0.567^{* * *}$ & $(5.54)$ & & & & & $0.469^{* * *}$ & $(3.69)$ \\
\hline Buyback repetition & 0.112 & $(1.43)$ & $0.300^{* * *}$ & $(2.52)$ & $0.313^{* *}$ & $(2.51)$ & & & & & 0.046 & $(0.60)$ \\
\hline Size & $0.297^{* * *}$ & $(5.56)$ & $0.287^{* * *}$ & $(4.84)$ & $0.211^{* * *}$ & $(3.12)$ & & & & & $0.152^{* * *}$ & $(3.60)$ \\
\hline Market-to-book & 0.039 & (1.63) & $0.049^{*}$ & $(1.93)$ & 0.054 & $(2.05)$ & & & & & 0.023 & $(1.02)$ \\
\hline Excess returns & $1.131^{* * *}$ & $(3.49)$ & $1.432^{* * *}$ & $(3.74)$ & $1.536^{* * *}$ & $(3.90)$ & & & & & $1.040^{* * *}$ & $(3.26)$ \\
\hline Leverage & $0.624^{* *}$ & $(2.25)$ & $0.654^{* *}$ & $(2.37)$ & $0.645^{* *}$ & $(2.22)$ & & & & & 0.305 & $(1.06)$ \\
\hline Options & -0.105 & $(-0.77)$ & -0.144 & $(-0.69)$ & -0.148 & $(-0.80)$ & & & & & 0.152 & $(0.63)$ \\
\hline Convertible debt & -0.355 & $(-0.17)$ & 0.859 & $(0.39)$ & 0.715 & $(0.35)$ & & & & & 0.525 & $(0.20)$ \\
\hline No. of analysts & -0.003 & $(-0.37)$ & -0.004 & $(-0.58)$ & -0.004 & $(-0.54)$ & & & & & 0.003 & $(0.35)$ \\
\hline Standard deviation & 0.190 & $(0.10)$ & -0.438 & $(-0.25)$ & -0.378 & $(-0.20)$ & & & & & -2.535 & $(-1.23)$ \\
\hline Cash & 0.273 & $(0.84)$ & 0.539 & $(1.43)$ & $0.615^{*}$ & $(1.66)$ & & & & & -0.085 & $(-0.23)$ \\
\hline Ownership concentration & -0.003 & $(-0.80)$ & -0.003 & $(-0.97)$ & -0.003 & $(-0.93)$ & & & & & $-0.015^{* * *}$ & $(-3.78)$ \\
\hline Dividend payout & 0.001 & $(0.22)$ & 0.000 & $(-0.18)$ & -0.001 & $(-0.24)$ & & & & & -0.003 & $(-1.36)$ \\
\hline Dividend yield & 0.020 & $(0.63)$ & 0.029 & $(0.89)$ & 0.033 & $(0.96)$ & & & & & 0.038 & $(1.09)$ \\
\hline Gender & & & & & & & -0.078 & $(-0.25)$ & $0.502^{* *}$ & $(2.36)$ & -0.011 & $(-0.03)$ \\
\hline Nationality & & & & & & & 0.189 & $(1.51)$ & $0.360^{* * *}$ & $(2.74)$ & 0.191 & $(1.52)$ \\
\hline Ln(age) & & & & & & & $0.631^{*}$ & $(1.74)$ & -0.191 & $(-0.48)$ & $1.079^{* * *}$ & $(2.88)$ \\
\hline Founder & & & & & & & 0.116 & $(0.75)$ & 0.161 & $(0.99)$ & -0.005 & $(-0.04)$ \\
\hline Tenure as CEO & & & & & & & $0.360^{* * *}$ & $(2.85)$ & $0.302^{* *}$ & $(2.20)$ & $0.206^{*}$ & $(1.91)$ \\
\hline Tenure in the firm & & & & & & & $-0.530^{* * *}$ & $(-4.06)$ & $-0.353^{* * *}$ & $(-2.78)$ & $-0.439^{* * *}$ & $(-3.54)$ \\
\hline Internally & & & & & & & 0.178 & $(1.20)$ & $0.277^{*}$ & $(1.69)$ & 0.141 & $(1.01)$ \\
\hline Number of companies & & & & & & & & & & & & \\
\hline worked for & & & & & & & -0.183 & $(-1.58)$ & -0.022 & $(-0.20)$ & -0.176 & $(-1.60)$ \\
\hline Number of directorships & & & & & & & & & & & & \\
\hline held & & & & & & & $0.172^{* *}$ & $(2.17)$ & 0.131 & $(1.53)$ & $0.144^{*}$ & $(1.87)$ \\
\hline Business education & & & & & & & $0.279^{*}$ & $(1.83)$ & 0.222 & $(1.59)$ & 0.172 & $(1.12)$ \\
\hline
\end{tabular}




\begin{tabular}{|c|c|c|c|c|c|c|}
\hline Industry/year dummy & $\checkmark$ & $\checkmark$ & $\checkmark$ & $\checkmark$ & $\checkmark$ & $\checkmark$ \\
\hline Pseudo R ${ }^{2}(\%)$ & 42.76 & 43.18 & 39.46 & 8.42 & 13.59 & 56.88 \\
\hline Obs. & 251 & 251 & 251 & 225 & 225 & 201 \\
\hline
\end{tabular}

Notes: This table presents the results on the two-stage Tobit regressions for estimating the determinants of the completion rates for a sample of 400 announcements of intention to buy back shares in the open market from 1997 to 2006 in the UK. The dependent variable is the Completion Rate, which is the percentage of the repurchased shares relative to the amount targeted at the time of the announcement. The independent variables are defined as in Table 3 and all continuous control variables are winsorized at the $1^{\text {st }}$ and $99^{\text {th }}$ percentiles. The two-tailed Tobit models are truncated at $0 \%$ and $100 \%$. The $t$-statistics are based on cluster adjusted robust standard errors at the firm level (Petersen, 2009) and are reported in parentheses.

* Statistical significance at the $10 \%$ level.

** Statistical significance at the 5\% level.

${ }^{* * * *}$ Statistical significance at the $1 \%$ level. 
Table 6

Tobit regressions on the robustness of the drivers of buyback completion rates.

Cons

CEO overconfidence

IV-Information disclosure

Initiation lag

Buyback repetition

Buyback reputation

Size

Market-to-book

Excess returns

Leverage

Options

Convertible debt

No. of analysts

Standard deviation

Cash

Ownership concentration

Dividend payout

Dividend yield

Gender

Nationality

Ln(age)

Founder

Tenure as CEO

Tenure in the firm

Internally

Number of companies

worked for

Number of directorships held

Business education

Industry /year dummy

\begin{tabular}{|c|c|c|c|c|c|c|c|}
\hline \multicolumn{2}{|c|}{ Buyback Information $=1$} & \multicolumn{2}{|c|}{ Buyback Information $=0$} & \multicolumn{2}{|c|}{ Buyback Repetition $=1$} & \multicolumn{2}{|c|}{ Buyback Repetition $=0$} \\
\hline Coef. & $t$-stat & Coef. & $t$-stat & Coef. & t-stat & Coef. & $t$-stat \\
\hline $2.671^{*}$ & $(1.83)$ & $2.433^{*}$ & $(1.85)$ & 3.051 & $(1.46)$ & 3.051 & $(1.46)$ \\
\hline $0.173^{* * *}$ & $(2.52)$ & -0.099 & $(-0.28)$ & 0.057 & $(0.20)$ & 0.057 & $(0.20)$ \\
\hline & & & & $1.014^{* * *}$ & $(7.11)$ & $0.501^{* * *}$ & $(3.77)$ \\
\hline$-0.089^{* * *}$ & $(-3.77)$ & -0.023 & $(-1.16)$ & $-0.158^{* * *}$ & $(-5.57)$ & $-0.158^{* * *}$ & $(-5.57)$ \\
\hline $0.397^{* * *}$ & $(3.06)$ & 0.078 & $(0.63)$ & & & & \\
\hline-0.032 & $(-0.33)$ & 0.044 & $(0.58)$ & & & & \\
\hline $0.249^{* * *}$ & $(3.93)$ & $0.272^{* * *}$ & $(3.32)$ & $0.344^{* * *}$ & $(4.55)$ & $0.157^{*}$ & $(1.92)$ \\
\hline $0.065^{* *}$ & $(2.28)$ & -0.029 & $(-1.61)$ & 0.0115 & $(0.42)$ & 0.033 & $(0.91)$ \\
\hline $0.874^{* *}$ & $(2.08)$ & $1.037^{* * *}$ & $(2.61)$ & $1.794^{* * *}$ & (3.82) & $1.794^{* * *}$ & (3.82) \\
\hline 0.340 & (1.34) & 0.440 & $(1.36)$ & $1.045^{* * *}$ & $(2.96)$ & $1.045^{* * *}$ & $(2.96)$ \\
\hline-2.619 & $(-0.06)$ & -0.407 & $(-0.85)$ & $-0.109^{* *}$ & $(-2.31)$ & $-0.109^{* *}$ & $(-2.31)$ \\
\hline$-7.287^{*}$ & $(-1.90)$ & -0.982 & $(-0.30)$ & -0.101 & $(-1.63)$ & -0.101 & $(-1.63)$ \\
\hline 0.011 & (1.32) & -0.014 & $(-1.40)$ & 0.011 & $(0.93)$ & 0.011 & $(0.93)$ \\
\hline-1.981 & $(-1.00)$ & $5.448^{*}$ & $(1.65)$ & -1.090 & $(-0.33)$ & -1.090 & $(-0.33)$ \\
\hline-0.198 & $(-0.35)$ & -0.501 & $(-1.26)$ & 0.044 & $(0.06)$ & 0.044 & $(0.06)$ \\
\hline$-0.010^{* * *}$ & $(-3.52)$ & -0.002 & $(-0.69)$ & $-0.023^{* * *}$ & $(-4.19)$ & $-0.023^{* * *}$ & $(-4.19)$ \\
\hline$-0.004^{*}$ & $(-1.75)$ & 0.001 & $(0.25)$ & $-0.007^{* *}$ & $(-2.40)$ & $-0.007^{* *}$ & $(-2.40)$ \\
\hline 0.054 & $(1.60)$ & 0.029 & $(0.85)$ & 0.027 & $(0.51)$ & 0.027 & $(0.51)$ \\
\hline 0.456 & (1.15) & & & $0.412^{*}$ & (1.74) & $0.412^{*}$ & (1.74) \\
\hline $0.250^{* *}$ & (2.19) & 0.104 & (1.14) & $0.398^{* * *}$ & $(3.50)$ & $0.398^{* * *}$ & $(3.50)$ \\
\hline-0.542 & $(-1.56)$ & $-0.743^{* *}$ & $(-2.39)$ & -0.665 & $(-1.44)$ & -0.665 & $(-1.44)$ \\
\hline 0.104 & $(0.88)$ & 0.314 & $(2.05)$ & 0.060 & $(0.37)$ & 0.060 & $(0.37)$ \\
\hline $0.346^{* * *}$ & (3.64) & 0.058 & $(0.58)$ & $0.343^{* *}$ & (2.29) & $0.343^{* *}$ & (2.29) \\
\hline$-0.227^{* *}$ & $(-2.27)$ & -0.044 & $(-0.37)$ & $-0.260^{* *}$ & $(-2.21)$ & $-0.260^{* *}$ & $(-2.21)$ \\
\hline 0.191 & (1.53) & -0.120 & $(-0.91)$ & 0.112 & $(0.43)$ & 0.112 & $(0.43)$ \\
\hline-0.052 & $(-0.56)$ & -0.038 & $(-0.55)$ & -0.094 & $(-0.82)$ & -0.094 & $(-0.82)$ \\
\hline 0.001 & $(0.02)$ & -0.071 & $(-0.93)$ & 0.072 & $(0.76)$ & 0.072 & $(0.76)$ \\
\hline 0.182 & (1.53) & 0.107 & $(0.72)$ & -0.013 & $(-0.09)$ & -0.013 & $(-0.09)$ \\
\hline$\checkmark$ & & $\checkmark$ & & $\checkmark$ & & $\checkmark$ & \\
\hline
\end{tabular}




\begin{tabular}{|c|c|c|c|c|}
\hline Pseudo $\mathrm{R}^{2}(\%)$ & 61.48 & 60.75 & 69.75 & 69.75 \\
\hline Obs & 188 & 179 & 170 & 164 \\
\hline
\end{tabular}

. This table presents the results on the two-stage Tobit regressions for assessing the drivers of the buyback completion rates. The dependent variable is the Completion Rate, which is the percentage of the repurchased shares relative to the amount targeted at the time of the announcement. The sample is comprised of 400 announcements of the firm's intention to buy back shares in the open market from 1997 to 2006 in the UK. The table presents the results for two sample partitions. First, the partitioned sample based on those firms that disclose explicit information about their intended buyback programs (buyback information $=1$ ) and those which do not disclose any information (buyback information $=0$ ). Second, the partitioned sample based on firms that have made a buyback announcement in the past (buyback repetition =1) and those that did not make such an announcement before the current buyback program (buyback repetition $=0$ ). The independent variables are defined as in Table 3 and all continuous control variables are winsorized at the $1^{\text {st }}$ and $99^{\text {th }}$ percentiles. The $t$-statistics are based on cluster adjusted robust standard errors at the firm level (Petersen, 2009) and are reported in parentheses.

* Statistical significance at the $10 \%$ level.

** Statistical significance at the 5\% level.

${ }^{* * *}$ Statistical significance at the $1 \%$ level. 
Table 7

Logit regressions on disclosing explicit buyback information.

\begin{tabular}{|c|c|c|c|c|}
\hline & Coef. & $t$-stat & Coef. & $t$-stat \\
\hline Cons & -7.200 & $(-0.91)$ & $-11.465^{*}$ & $(-1.90)$ \\
\hline CEO overconfidence & $4.419^{* *}$ & $(2.36)$ & $2.397^{* * *}$ & $(2.90)$ \\
\hline Buyback reputation & -0.193 & $(-0.57)$ & & \\
\hline Buyback repetition & $-1.658^{* * *}$ & $(-2.90)$ & $-1.379^{* * *}$ & $(-3.07)$ \\
\hline Size & $0.360^{* * *}$ & $(2.99)$ & $0.316^{* * *}$ & $(4.96)$ \\
\hline Market-to-book & 0.079 & $(0.69)$ & & \\
\hline Excess returns & $-5.824^{* * * *}$ & $(-2.70)$ & $-4.274^{* * * *}$ & $(-2.59)$ \\
\hline Leverage & -1.452 & $(-0.94)$ & & \\
\hline Options & 0.128 & $(0.30)$ & & \\
\hline Convertible debt & -0.031 & $(-1.09)$ & & \\
\hline No. of analysts & 0.002 & $(0.04)$ & 0.018 & $(0.61)$ \\
\hline Standard deviation & 0.132 & $(1.00)$ & 5.295 & $(0.52)$ \\
\hline Cash & -1.170 & $(-0.50)$ & -0.087 & $(-0.04)$ \\
\hline Ownership concentration & 0.000 & $(-0.02)$ & 0.012 & (1.03) \\
\hline Dividend payout & -0.004 & $(-0.24)$ & & \\
\hline Dividend yield & 0.163 & $(0.80)$ & & \\
\hline Gender & & & 1.533 & $(0.99)$ \\
\hline Nationality & $1.137^{*}$ & $(1.89)$ & $1.213^{* * *}$ & $(2.55)$ \\
\hline Ln(age) & 2.523 & $(1.35)$ & 2.589 & $(1.77)$ \\
\hline Founder & 0.517 & $(0.75)$ & -0.102 & $(-0.19)$ \\
\hline Tenure as CEO & -0.361 & $(-0.57)$ & 0.006 & $(0.01)$ \\
\hline Tenure in the firm & -0.069 & $(-0.10)$ & -0.065 & $(-0.12)$ \\
\hline Internally & -0.377 & $(-0.50)$ & -0.288 & $(-0.49)$ \\
\hline Number of companies worked for & 0.079 & $(0.15)$ & 0.412 & $(0.94)$ \\
\hline Number of directorships held & -0.096 & $(-0.22)$ & 0.205 & $(0.57)$ \\
\hline Business education & 1.822 & $(2.29)$ & $1.220^{* *}$ & (2.09) \\
\hline Industry/year dummy & $\checkmark$ & & $\checkmark$ & \\
\hline Pseudo $\mathrm{R}^{2}(\%)$ & 29.38 & & 25.20 & \\
\hline Log likelihood & -62.630 & & -85.705 & \\
\hline Obs & 237 & & 260 & \\
\hline
\end{tabular}

Notes: This table presents the results on the logit regressions for assessing the drivers of disclosing explicit information about the intended buyback program. The sample is comprised of 400 announcements of the firm's intention to buy back shares in the open market from 1997 to 2006 in the UK. The dependent variable is the dummy variable Information disclosure, which takes the value of one if the announcement contains explicit information about the intended buyback program and zero otherwise. The variables are defined as in Table 3 and all continuous control variables are winsorized at the $1^{\text {st }}$ and $99^{\text {th }}$ percentiles. The $t$-statistics are based on cluster adjusted robust standard errors at the firm level (Petersen, 2009) and are reported in parentheses.

"Statistical significance at the $10 \%$ level.

${ }^{* *}$ Statistical significance at the $5 \%$ level.

${ }^{* * *}$ Statistical significance at the $1 \%$ level. 
Table 8

Hazard models on the drivers of buyback completion rates.

\begin{tabular}{|c|c|c|c|c|}
\hline & Hazard ratio & Z-stat & $\begin{array}{c}\text { Hazard } \\
\text { ratio }\end{array}$ & Z-stat \\
\hline Information disclosure & $1.842^{* *}$ & $(2.50)$ & $2.260^{* *}$ & $(2.70)$ \\
\hline CEO overconfidence & $2.028^{* * * *}$ & $(3.30)$ & $2.055^{* * *}$ & $(3.34)$ \\
\hline Buyback reputation & $2.105^{* * *}$ & $(3.53)$ & $2.132^{* *}$ & $(2.82)$ \\
\hline Buyback repetition & $1.864^{* * * *}$ & (3.04) & $2.035^{* * *}$ & $(4.06)$ \\
\hline Size & $1.449^{* * * *}$ & $(4.22)$ & $1.328^{* * *}$ & $(3.09)$ \\
\hline Market-to-book & $1.072^{*}$ & $(1.82)$ & 1.023 & $(0.34)$ \\
\hline Excess returns & 3.208 & $(1.52)$ & $1.924^{* * *}$ & $(2.62)$ \\
\hline Leverage & 1.629 & $(0.80)$ & 0.364 & $(-1.29)$ \\
\hline Options & 0.000 & $(-0.41)$ & 0.590 & $(0.55)$ \\
\hline Convertible debt & 0.000 & $(-1.08)$ & 0.001 & $(-0.72)$ \\
\hline No. of analysts & 1.024 & $(1.15)$ & 1.040 & $(1.59)$ \\
\hline Standard deviation & $0.000^{* *}$ & $(-2.82)$ & $0.000^{* *}$ & $(-2.53)$ \\
\hline Cash & 1.738 & $(0.53)$ & 3.779 & $(0.97)$ \\
\hline Ownership concentration & $0.986^{* *}$ & $(-2.23)$ & $0.968^{* *}$ & $(-3.35)$ \\
\hline Dividend payout & 1.005 & $(0.90)$ & 1.006 & $(0.86)$ \\
\hline Dividend yield & $0.854^{* *}$ & $(-2.06)$ & $0.802^{*}$ & $(-1.92)$ \\
\hline Gender & & & 0.225 & $(-1.29)$ \\
\hline Nationality & & & 1.595 & $(1.52)$ \\
\hline Ln(age) & & & 0.889 & $(-0.12)$ \\
\hline Founder & & & 1.008 & $(0.02)$ \\
\hline Tenure as CEO & & & 1.818 & $(1.92)$ \\
\hline Tenure in the firm & & & $0.303^{* * *}$ & $(-3.46)$ \\
\hline Internally & & & 0.625 & $(-1.19)$ \\
\hline Number of companies worked for & & & $0.438^{* *}$ & $(-2.68)$ \\
\hline Number of directorships held & & & 0.891 & $(-0.53)$ \\
\hline Business education & & & 0.899 & $(-0.26)$ \\
\hline Log likelihood & -566.74 & & -371.04 & \\
\hline Obs & 257 & & 243 & \\
\hline \multicolumn{5}{|c|}{$\begin{array}{l}\text { Notes: The dependent variable is a dummy variable that takes the value of if a firm has } \\
\text { conducted a buyback program and zero otherwise. All the variables are defined as in Table } 3 \\
\text { and all continuous control variables are winsorized at the } 1^{\text {st }} \text { and } 99^{\text {th }} \text { percentiles. The time } \\
\text { variable used in the estimation is initiation lag in days. The z-statistics are based on cluster } \\
\text { adjusted robust standard errors at the firm level (Petersen, 2009) and are reported in parentheses. } \\
{ }^{*} \text { Statistical significance at the } 10 \% \text { level. } \\
\text { *** Statistical significance at the } 5 \% \text { level. } \\
{ }^{* * * *} \text { Statistical significance at the } 1 \% \text { level. }\end{array}$} \\
\hline
\end{tabular}

